\title{
SILICON ACCUMULATION AND WATER DEFICIT TOLERANCE IN Brachiaria GRASSES
}

\author{
Suzana Pereira de Melo ${ }^{1}$; Gaspar Henrique Korndörfer ${ }^{2 *}$; Clotilde Maria Korndörfer ${ }^{3}$; Regina \\ Maria Quintão Lana²; Denise Garcia de Santana ${ }^{2}$

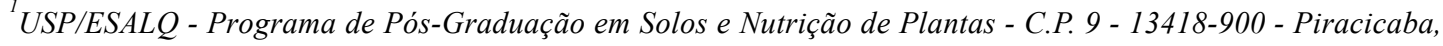 \\ $S P$ - Brasil \\ ${ }^{2} U F U / I C I A G$ - Instituto de Ciências Agrárias - C.P. 593 - 38400-902 - Uberlândia, MG - Brasil. \\ ${ }^{3}$ UFU/FAMEV - Faculdade de Medicina Veterinária - C.P. 593 - 38400-902 - Uberlândia, MG - Brasil. \\ *Corresponding author <ghk@triang.com.br>
}

\begin{abstract}
The beneficial effects of silicon ( $\mathrm{Si}$ ) fertilization have been observed for several plant species, especially when submitted to stress, either biotic or abiotic. Among the possible reasons for the greater adaptability and resistance of brachiaria grass in areas of low fertility soils in Brazilian savanna, stands its capacity of absorbing and accumulating Si in aerial parts. To evaluate the effect of Si on dry matter yield of Brachiaria decumbens Stapf and Brachiaria brizantha Hochst, grown under two soil moisture regimes, a trial was set up in a completely randomized design factorial scheme $(5 \times 2 \times 2)$, with five Si rates: $(0 ; 242$; 484; 968 and $1,452 \mathrm{~kg} \mathrm{ha}^{-1}$ ), two soil water tensions ( $60 \%$ and $80 \%$ of field capacity) and the two brachiaria species. The experiment was installed in a greenhouse, using one of the most representative soils in the region under cerrado, Typic Haplustox. Both brachiaria species can be considered Si-accumulating plants, since they present high Si contents in their aerial parts. Application of Si to the soil increased the contents of this element in both grass species but did not change their tolerance to water deficit, and did not affect dry matter yield.
\end{abstract}

Key words: calcium silicate, pasture, water stress, soil moisture

\section{ACÚMULO DE SILÍCIO E TOLERÂNCIA AO DÉFICIT HÍDRICO EM CAPINS DO GÊNERO Brachiaria}

\begin{abstract}
RESUMO: Efeitos benéficos da adubação com silício (Si) têm sido observados em várias espécies vegetais, especialmente quando estas estão submetidas a estresse biótico ou abiótico. Entre as possíveis razões para a maior adaptabilidade e resistência do capim braquiária nas áreas de baixa fertilidade do solo das regiões do cerrado brasileiro, esta associada à sua capacidade em absorver e acumular Si na parte aérea. Este trabalho teve como objetivo avaliar o efeito da aplicação de Si sobre a produção de matéria seca de duas espécies das gramíneas Brachiaria decumbens Stapf e Brachiaria brizantha Hochst, cultivadas sob dois regimes de umidade no solo. Os ensaios foram instalados em delineamento inteiramente casualizado, em esquema fatorial $(5 \times 2 \times 2)$ com cinco doses de $\operatorname{Si}\left(0,242,484,968\right.$ e $\left.1452 \mathrm{~kg} \mathrm{ha}^{-1}\right)$, duas tensões de água no solo $(60 \%$ e $80 \%$ da capacidade de campo) e as duas espécies de braquiária. O experimento foi instalado em casa-de-vegetação, utilizando um dos mais representativos solos da região sob cerrado, Latossolo Vermelho-Amarelo. As duas espécies de braquiária podem ser consideradas plantas acumuladoras de $\mathrm{Si}$, por apresentarem altos teores de Si na parte aérea. A aplicação de Si no solo aumentou os teores deste elemento nas duas espécies de gramíneas testadas, mas não modificou a tolerância das duas gramíneas ao déficit hídrico, e não afetou a produção de matéria seca.
\end{abstract}

Palavras-chave: silicato de cálcio, pastagem, estresse, umidade do solo

\section{INTRODUCTION}

Silicon ( $\mathrm{Si}$ ) has received little attention from plant nutrition scientists, most likely because it is not included in the group of elements considered as essential to plants. Notwithstanding, beneficial effects of $\mathrm{Si}$ have been demonstrated for many plant species, especially when these plants are submitted to some type of stress, whether biotic or abiotic (Takahashi, 1995; Korndörfer et al., 1999; Faria, 2000; Datnoff et al.,
2001). By and large, grasses are classified as Si-accumulating plants, since they deposit this element in cell walls, in the cell lumen and in extracellular sites. Silicon absorbed by the roots in the form of monosilicic acid $\left(\mathrm{H}_{4} \mathrm{SiO}_{4}\right)$ is carried through the plant and deposited in the leaves. Incorporated within the cells in the cell wall, especially in epidermal, stomatal and leaf trichome cells, or deposited, together with other elements, giving rise to amorphous deposits known as phytoliths (Jones \& Handreck, 1967; Yoshida, 1965). 
One of the reasons, still little discussed, for the ruggedness shown by brachiaria grasses when developing under savanna soils, could be its greater capacity in absorbing and accumulating Si. The role played by $\mathrm{Si}$ in these plants can be linked to a reduction in the toxic effects of aluminum, manganese and iron, as previously observed for other grasses, and also because it is responsible for regulating transpiration, which is the likely reason for the resistance shown by this grass to water deficits which occur in the savanna, in addition to protecting the leaves against pest and disease attacks (Cocker et al., 1998; Ma et al., 1997; Datnoff et al., 2001).

The objective of this work was to study the effect of silicon fertilization on silicon accumulation by tropical forages (brachiaria grass), on their tolerance to water stress and on dry matter yield, when grown, under greenhouse conditions.

\section{MATERIAL AND METHODS}

The experiment was conducted in the greenhouse over surface samples $(0-20 \mathrm{~cm})$ of a medium-textured Typic Haplustox, with low Si content $\left(5.0 \mathrm{mg} \mathrm{dm}^{-3}\right.$ - extracted with acetic acid $0.5 \mathrm{M}$ ), representative of extensive pasture-growing areas. The soil chemical characteristics before installation of the experiment were: $\mathrm{pH}=5.2$ $\left(\mathrm{H}_{2} \mathrm{O}\right) ; \mathrm{P}=1.4 \mathrm{mg} \mathrm{dm}^{-3} ; \mathrm{K}=48.0 \mathrm{mg} \mathrm{dm}^{-3} ; \mathrm{Al}=9 \mathrm{mmol}$ $\mathrm{dm}^{-3} ; \mathrm{Ca}=2 \mathrm{mmol} \mathrm{dm}^{-3} ; \mathrm{Mg}=1 \mathrm{mmol} \mathrm{dm}^{-3} ; \mathrm{CEC}=63.3^{\mathrm{c}}$ mmol $\mathrm{dm}^{-3} ; \mathrm{V}=6.0 \% ; \mathrm{m}=71.0 \%$; O.M. $=2.1 \mathrm{dag} \mathrm{kg}^{-1}$. Soils physical characteristics were: Coarse sand $=$ $436 \mathrm{~g} \mathrm{~kg}^{-1}$; Fine sand $=345 \mathrm{~g} \mathrm{~kg}^{-1}$; Silt $=27 \mathrm{~g} \mathrm{~kg}^{-1}$; Clay $=192 \mathrm{~g} \mathrm{~kg}^{-1}$. The textural analysis was performed through the pipette method (EMBRAPA, 1997).

Treatments consisted on the addition of five calcium silicate rates: $0 ; 1,000 ; 2,000 ; 4,000$; and $6,000 \mathrm{~kg} \mathrm{ha}^{-1}$, corresponding to $0 ; 242 ; 484 ; 968$; and $1452 \mathrm{~kg} \mathrm{ha}^{-1} \mathrm{Si}$; two soil moisture levels (field capacity, $\mathrm{FC}=$ maximum water retention capacity): $80 \% \quad \mathrm{FC}$ and $60 \%$ FC; and two grass species: Brachiaria decumbens (brachiaria grass) and Brachiaria brizantha (signal grass). Wollastonite $\left(\mathrm{CaSiO}_{3}\right)$ was utilized as the $\mathrm{Si}$ source $\mathrm{Si}=24.3 \% ; \mathrm{CaO}=42.0 \% ; \mathrm{MgO}=1.5 \%$ ). To make up for the effects of Wollastonite on $\mathrm{pH}$, as well as on soil $\mathrm{Ca}$ and $\mathrm{Mg}$ contents, calcium carbonate $\left(\mathrm{CaCO}_{3}\right)$ was applied at rates of 4,$511 ; 3,759 ; 3,007 ; 1,504$ and $0 \mathrm{~kg} \mathrm{ha}^{-1}$; magnesium sulfate $\left(\mathrm{MgSO}_{4}\right)$ was also applied at the following rates: $497 ; 414 ; 331 ; 166$ and $0 \mathrm{~kg} \mathrm{ha}^{-1}$ respectively, for treatments containing $0,242,484,968$ and $1,452 \mathrm{~kg} \mathrm{ha}^{-1} \mathrm{Si}$. This procedure allowed all pots containing soil to attain the similar $\mathrm{pH}, \mathrm{Ca}$ and $\mathrm{Mg}$ values after incubation.

After 30 days of incubation ( $80 \%$ of FC) the brachiaria seeds were sown at the rate of 50 seeds per pot. Pots were watered daily until total seed germination occurred. Thinning was performed five days after germi- nation, leaving 20 plants per pot and soil moisture was controlled there after, with half of the pots maintained at $80 \%$ and the other half maintained at $60 \%$ FC. Three cuts were performed; the first 30 days after germination, the second 22 days after the first, and the third 26 days after the second.

Trials were set up in completely randomized experimental design, in a $5 \times 2 \times 2$ factorial scheme: five Si rates, two moisture levels and two brachiaria species $(\mathrm{n}=5)$ treatment means were compared by the Tukey test $(P=0.05)$.

Two soil samplings were performed, one right after the incubation period and the other at the end of the experiment (after the third cut). Samples were analyzed for $\mathrm{pH}\left(\mathrm{CaCl}_{2}\right)$, Si (Korndörfer et al., 1999), $\mathrm{Ca}$ and $\mathrm{Mg}$ (Malavolta et al., 1997). The dried plant material was ground in a Willey-type mill ( $2 \mathrm{~mm}$ sieve) and analyzed for Si content, according to Elliot \& Snyder (1991).

\section{RESULTS AND DISCUSSION}

The Si contents available in the soil samples collected at the end of the experiment, i.e., 110 days after silicate application, increased as the applied Si rates increased, going from $5.8 \mathrm{mg} \mathrm{dm}^{-3}$ to $27.9 \mathrm{mg} \mathrm{dm}^{-3}$, respectively, for the rates of $0 \mathrm{~kg} \mathrm{ha}^{-1}$ and $1,452 \mathrm{~kg} \mathrm{ha}^{-1}$, confirming the high reactivity of the calcium silicate (Wollastonite). The $\mathrm{pH}\left(\mathrm{CaCl}_{2}\right)$ was maintained at 4.8.

The two grass species have different behaviors with respect to $\mathrm{Si}$ extraction from the soil $B$. brizantha absorbed less Si than $B$. decumbens, thus leaving a greater amount of residual $\mathrm{Si}$ in the soil. The soil cultivated with $B$. decumbens presented $17.5 \mathrm{mg} \mathrm{dm}^{-3} \mathrm{Si}$ at the end of the experiment, while the soil cultivated with $B$. brizantha presented $20.3 \mathrm{mg} \mathrm{dm}^{-3} \mathrm{Si}$.

The two field capacities applied to the soil presented different behaviors in relation to soil $\mathrm{Si}$ at the end of the experiment. A smaller soil Si content $\left(18.0 \mathrm{mg} \mathrm{dm}^{-3}\right)$ was observed at the higher water content, i.e., when there was greater soil water availability. Conversely, the soil residual $\mathrm{Si}$ was greater $\left(19.8 \mathrm{mg} \mathrm{dm}^{-3}\right)$ at the lower water content. The smaller Si absorption or accumulation by the plants in treatments receiving less water can partially explain the differences in soil Si contents, i.e., the greater the extraction by the plant, the smaller the availability in the soil.

With regard to Si content in the aerial part of the plants, $B$. decumbens $\left(9.8 \mathrm{~g} \mathrm{~kg}^{-1}\right)$ was superior to $B$. brizantha $\left(9.2 \mathrm{~g} \mathrm{~kg}^{-1}\right)$ for the three cuts, presenting differences in the first two cuts (Figure 1). These differences in Si contents of the aerial part indicate a differential behavior between the two species relatively to $\mathrm{Si}$ absorption and accumulation. When the sum of the three cuts is considered, an increase of approximately $170 \%$ in the amount of accumulated Si was observed in the aerial part, 
i.e., from 142.6 to $450.9 \mathrm{mg}^{-1}$ pot $^{-1}$, respectively in the control and at the $1,452 \mathrm{~kg} \mathrm{ha}^{-1}$ rate (Table 1), and that demonstrates that the two brachiaria species, as well as the majority of grasses, are considered as $\mathrm{Si}$-accumulating species (Elawad \& Green, 1979; Korndörfer et al., 1999; Rodrigues, 2000).

There was greater $\mathrm{Si}$ accumulation in the plant when soil moisture was maintained at $80 \%$ of the FC (Figure 2). The $80 \%$ FC accumulated about 1.4-fold more Si than the $60 \%$ FC when the sum of the three cuts is considered, i.e., silicon absorption increased as water availability increased, and that corroborates the hypothesis that $\mathrm{Si}$ is passively absorbed via mass flow, following the water during the transpiration process, as proposed by Jones \& Handreck (1967).

The accumulated $\mathrm{Si}$ (sum of the three cuts) was different between the two brachiaria species. $B$.

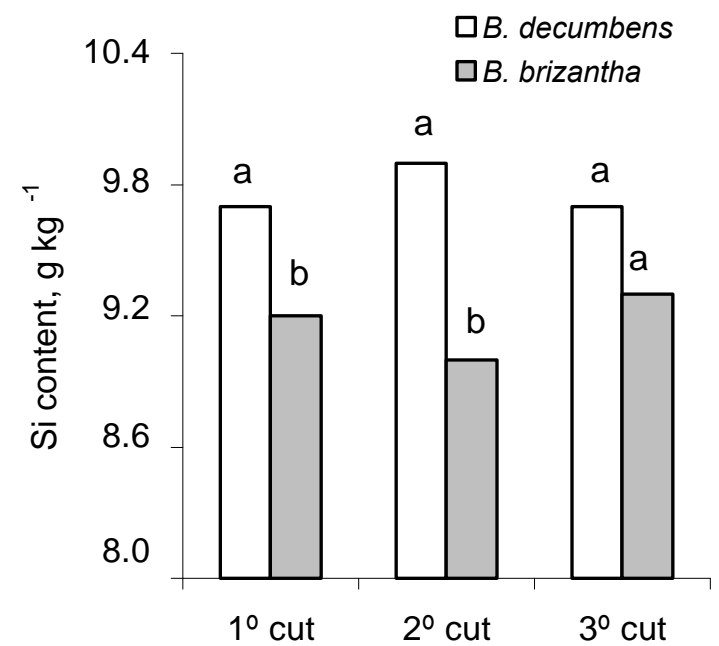

Figure 1 - Silicon content in the aerial part of two brachiaria species in three cuts (mean of two soil water tensions and five silicate rates).

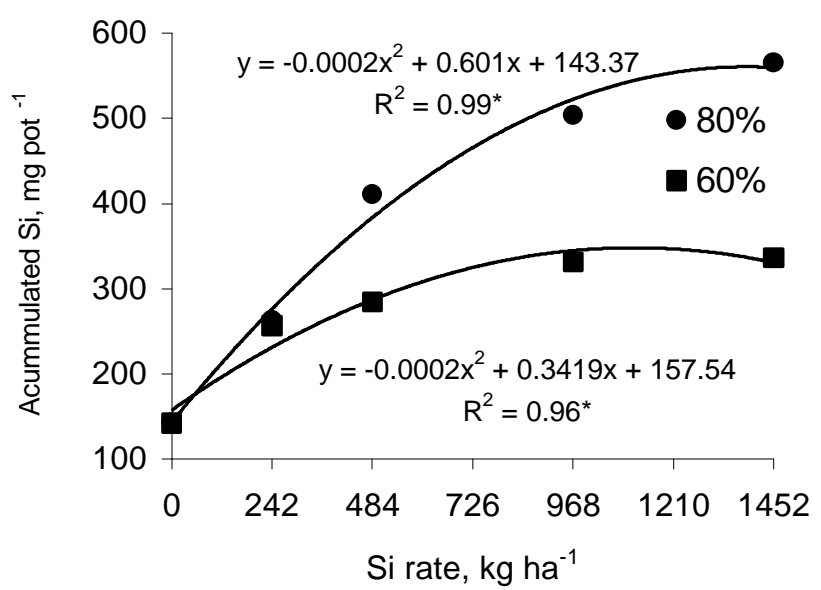

Figure 2 - Silicon accumulation in the aerial part of grasses on 80 and $60 \%$ field capacity. Sum of the three cuts over the mean of two brachiaria species. $*(P=0.05)$ decumbens accumulated approximately $8 \%$ more $\mathrm{Si}$ in its aerial part as compared to $B$. brizantha. When the three cuts are individually analyzed, it can be observed that the second cut accumulated the greatest amount of Si for both species, explaining the greater dry matter yield of this cut (Table 2). Clark et al. (1990), working with sorghum and millet grown in an acid soil with $60 \% \mathrm{Al}$ saturation and $\mathrm{pH} 4.0$, observed that for sorghum productivities equal to 325 to $3600 \mathrm{~kg} \mathrm{ha}^{-1}$, the accumulated Si ranged from 8.1 to $18.8 \mathrm{~g} \mathrm{~kg}^{-1}$, respectively. The accumulated $\mathrm{Si}$ in millet at productivities of 1,980 to $3,460 \mathrm{~kg} \mathrm{ha}^{-1}$, ranged from 27.9 to $43.4 \mathrm{~g} \mathrm{~kg}^{-1}$.

The soil water regimes influenced dry matter yield of the three cuts individually, and their sum. The $80 \%$ FC yielded $30 \%$ more dry matter than the $60 \%$ FC, i.e., the more available water in the soil, the greater the dry matter yield (Table 2).

No effect of Si application on dry matter yield was detected for any of the cuts or even for the sum of the three cuts. These results contradict those obtained by Korndörfer et al. (2001) in a field work conducted in the Triângulo Mineiro region, using a Typic Haplustox, for

Table 1 - Accumulated Si in the aerial part of grasses in each of three cuts and in the sum of the three cuts.

\begin{tabular}{|c|c|c|c|c|}
\hline \multirow{2}{*}{ Causes of Variation } & \multicolumn{4}{|c|}{$\begin{array}{c}\text { Accumulated } \mathrm{Si} \text { - aerial part of } \\
\text { grasses }\end{array}$} \\
\hline & $1^{\circ} \mathrm{Cut}$ & $2^{\circ} \mathrm{Cut}$ & $3^{\circ} \mathrm{Cut}$ & $\sum$ Cuts \\
\hline Soil Water Tension & \multicolumn{4}{|c|}{ - } \\
\hline $80 \% \mathrm{FC}$ & 96.3 & 112.4 & 122.6 & 377.0 \\
\hline $60 \% \mathrm{FC}$ & 71.0 & 162.9 & 86.9 & 270.4 \\
\hline F test & $*$ & $*$ & $*$ & $*$ \\
\hline Si rates $\left(\mathrm{kg} \mathrm{ha}^{-1}\right)$ & \multicolumn{4}{|c|}{ - } \\
\hline 0 & 48.9 & 44.1 & 49.1 & 142.6 \\
\hline 242 & 77.4 & 114.7 & 81.6 & 259.7 \\
\hline 484 & 82.3 & 156.9 & 108.3 & 347.6 \\
\hline 968 & 101.4 & 180.1 & 136.1 & 417.6 \\
\hline 1452 & 108.2 & 192.5 & 148.1 & 450.9 \\
\hline F test & $*$ & $*$ & $*$ & $*$ \\
\hline Species & \multicolumn{4}{|c|}{ - } \\
\hline Brachiaria decumbens & 83.1 & 137.0 & 115.8 & 336.8 \\
\hline Brachiaria brizantha & 84.1 & 138.3 & 93.7 & 310.6 \\
\hline F test & ns & ns & $*$ & $*$ \\
\hline Interactions & \multicolumn{4}{|c|}{ - } \\
\hline Tension x Rates & $*$ & $*$ & $*$ & $*$ \\
\hline Tension x Species & $*$ & ns & ns & ns \\
\hline Rates x Species & ns & $\mathrm{ns}$ & $*$ & ns \\
\hline $\begin{array}{l}\text { Rates x Species } \mathrm{x} \\
\text { Tension }\end{array}$ & ns & ns & ns & ns \\
\hline C.V. $(\%)$ & 12.4 & 32.4 & 16.6 & 16.6 \\
\hline
\end{tabular}

*Significant by the $\mathrm{F}$ test $(P<0.05)$ or n.s. $=$ not significant $(P>0.05)$. 
Table 2 - Dry matter yield for each cut and for the sum of the three cuts

\begin{tabular}{|c|c|c|c|c|}
\hline \multirow{2}{*}{ Causes of Variation } & \multicolumn{4}{|c|}{ Dry Matter } \\
\hline & $1^{\circ} \mathrm{Cut}$ & $2^{\circ} \mathrm{Cut}$ & $3^{\circ} \mathrm{Cut}$ & $\sum$ Cuts \\
\hline Soil Water Tension & \multicolumn{4}{|c|}{ - g pot $^{1} \ldots$} \\
\hline $80 \% \mathrm{FC}$ & 10.4 & 17.2 & 11.8 & 39.4 \\
\hline $60 \% \mathrm{FC}$ & 7.9 & 12.7 & 9.9 & 30.5 \\
\hline $\mathrm{F}$ test & $*$ & $*$ & $*$ & $*$ \\
\hline Si rates $\left(\mathrm{kg} \mathrm{ha}^{-1}\right)$ & \multicolumn{4}{|c|}{ - g pot ${ }^{1}$} \\
\hline 0 & 9.2 & 15.8 & 10.7 & 35.7 \\
\hline 242 & 9.8 & 14.1 & 11.1 & 35.0 \\
\hline 484 & 8.7 & 14.7 & 11.2 & 34.6 \\
\hline 968 & 9.1 & 16.3 & 11.1 & 36.5 \\
\hline 1452 & 9.1 & 14.1 & 9.9 & 33.1 \\
\hline F test & $*$ & $*$ & $*$ & $*$ \\
\hline Species & \multicolumn{4}{|c|}{ - g pot ${ }^{1} \ldots$} \\
\hline Brachiaria decumbens & 8.9 & 14.2 & 11.8 & 34.8 \\
\hline Brachiaria brizantha & 9.4 & 15.8 & 9.8 & 35.0 \\
\hline $\mathrm{F}$ test & ns & ns & $*$ & $*$ \\
\hline Interactions & \multicolumn{4}{|c|}{ - } \\
\hline Tension $\mathrm{x}$ Rates & $*$ & $*$ & $*$ & $*$ \\
\hline Tension x Species & $*$ & ns & ns & ns \\
\hline Rates x Species & ns & ns & $*$ & ns \\
\hline $\begin{array}{l}\text { Rates x Species x } \\
\text { Tension }\end{array}$ & ns & ns & ns & ns \\
\hline C.V. $(\%)$ & 10.9 & 25.3 & 18.0 & 15.5 \\
\hline
\end{tabular}

*Significant by the $\mathrm{F}$ test $(P<0.05)$ or $\mathrm{n} . \mathrm{s} .=$ not significant $(P>0.05)$.

which a $17 \%$ increase in $B$. decumbens dry matter yield as observed with the surface application of $2,000 \mathrm{~kg} \mathrm{ha}^{-1}$ calcium silicate.

The lack of dry matter yield response to Si application can be related, for the most part, to the fact that the experiment was conducted in a greenhouse, where the biotic stress was controlled. In other words, the fact that no type of attack by pests or diseases during the experimental period occurred, that could affect the vegetative development of the two grasses, inhibited the positive response of Si. However, this can be observed in the field, where plants are more susceptible to pests, such as frog hoper. In addition, no visual differences were observed in leaf architecture between treatments, suggesting that there was no difference in the photosynthetic rate that could increase dry matter yield, as observed by Marschner (1995).

$B$. brizantha yielded more dry matter in relation to $B$. decumbens in the first and second cuts. However, $B$. decumbens had a higher yield in the third cut. No difference was observed in the sum of the three cuts between the two brachiaria species with regard to dry matter yield. Some pasture evaluations conducted with $B$. decumbens and $B$. brizantha had similar dry matter yield for both species (Euclides et al., 1993).

For the tested species, Si did not regulate transpiration, as anticipated by Faria (2000), i.e., it did not improve the ability of the species to tolerate higher water stress. Two possible reasons for the lack of response to $\mathrm{Si}$ in the soil with less available water $(60 \% \mathrm{FC})$ could have been the species that were selected for the tests (brachiaria) and the water tension in the soil. On one hand, brachiaria are acknowledgedly very tolerant species to water deficit. On the other hand, it was not possible to detect visual differences between plants submitted to the two soil water regimes. This suggests that the $60 \%$ FC treatment was not sufficient to express the role Si plays on soil water deficit tolerance, contradicting results reported Agarie et al., (1998), Faria, (2000), and Ma et al., (2001).

\section{ACKNOWLEDGEMENTS}

To Drs. Gilberto F. Corrêa and George H. Snyder for their suggestions and important ideas, and for $\mathrm{Mr}$. Willian Faleiros de Moura for technical assistance. To CNPq, FAPEMIG and Fundação Banco do Brasil for financial support.

\section{REFERENCES}

AGARIE, S.; UCHIDA, H.; AGATA, W.; KUBOTA, F.; KAUFMAN, P.B. Effects of silicon on transpiration and leaf conductance in rice plants (Oryza sativa L.) Plant Production Science, v.1, p.89-95, 1998.

CLARK, R.B.; FLORES, C.I.; GOURLEY, L.M.; DUNCAN, R.R. Mineral element concentration and grain field of sorghum (Sorghum bicolor) and pearl millet (Penniserum glaucom) grow on acid soil. In: VAN BEUSICHEM, M.L. (Ed.) Plant nutrition - physiology and applications. Dordrecht: Kluwer Academic, 1990. p.391-396.

COCKER, K.M.; EVANS, D.E.; HODSON, M.J. The amelioration of aluminium toxicity by silicon in higher plants: solution chemistry or in plant mechanism? Physiologia Plantarum, v.104, p.608-614, 1998.

DATNOFF, L.E.; SNYDER, G.H.; KORNDÖRFER, G.H. Silicon in agriculture. Studies in plant science. Amsterdam: Elsevier, 2001. 403p.

ELAWAD, S.H.; GREEN, V.E. Silicon and the rice plant environment: a review of recent research. II Riso, v.28, p.235-253, 1979.

ELLIOT, C.L; SNYDER, G.H. Autoclave-induced digestion for the colorimetric determination of silicon in rice straw. Journal of Agriculture and Food Chemistry, v.39, p.1118-1119, 1991.

EMBRAPA. Centro Nacional de Pesquisa de Solos. Manual de métodos de análise de solo. 2.ed. Rio de Janeiro: EMBRAPA, CNPS, 1997. 212p.

EUCLIDES, V.P.B.; ZIMER, A.H.; OLIVEIRA M.P. Evolution of Brachiaria decumbens and Brachiaria brizantha under grazing. In: INTERNATIONAL GRASSLAND CONGRESS, 17., Austrália: Palmerston North, 1993. Proceedings. Palmerston Noth, 1993. p.19971998

FARIA, R.J. Influência do silicato de cálcio na tolerância do arroz de sequeiro ao déficit hídrico do solo. Viçosa: UFV, 2000. 47p. (Dissertação Mestrado)

JONES, L.H.P.; HANDRECK, K.A. Silica in soils, plant and animals. Advances in Agronomy, v.19, p.107-149, 1967.

KORNDÖRFER, G.H.; COELHO, N.M.; SNYDER, G.H.; MIZUTANI, C.T Avaliação de métodos de extração de silício para solos cultivados com arroz de sequeiro. Revista Brasileira de Ciência do Solo, v.23, p.101$106,1999$. 
KORNDÖRFER, C.M.; KORNDÖRFER, G.H.; PEÇANHA, M.R.; CORREA, G.F.; JUNQUEIRA NETO, A.A. Correção de acidez do solo com silicato de cálcio e o papel do silício na recuperação de pastagem de Brachiaria decumbens In: CONGRESSO BRASILEIRO DE CIÊNCIA DO SOLO, 28., Londrina, 2001. Anais. Londrina: SBCS, 2001. p. 144

MA, J.F.; SASAKI, M.; MATSUMOTO, H. Al-induced inhibition of root elongation in corn, Zea mays L. is overcome by $\mathrm{Si}$ addition. Plant and Soil, v.188, p.171-176, 1997.

MA, J.F.; MIYAKE. Y.; TAKAHASHI, E. Silicon as a beneficial element for crop plants. In: DATNOFF, L.E.; SNYDER, G.H.; KORNDÖRFER, G.H. Silicon in agriculture. Studies in plant science. Amsterdam: Elsevier, 2001. v.8, cap.2, p.17-39.

MALAVOlTA, E.; VITTI, G.C.; OLIVEIRA, S.A. Avaliação do estado nutricional das plantas: princípios e aplicações. 2.ed. Piracicaba: Associação Brasileira para Pesquisa da Potassa e Fosfato, 1997. 319p.

MARSCHNER, H. Mineral nutrition of higher plants. London: Academic Press, 1995. 889p.
RODRIGUES, F.A. Fertilização silicatada na severidade da queima das bainhas (Rhizoctonia solani Kühn) do arroz. Viçosa: UFV, 2000. 47p. (Dissertação - Mestrado)

TAKAHASHI, E. Uptake mode and physiological functions of silica. In: MATSUO, T.; KUMAZAWA, K.; ISHII, R. (Ed.) Science of the rice plant: physiology. Tokyo: Food and Agriculture Policy Research Center, 1995. p.420-433.

YOSHIDA, S. Chemical aspects of the role of silicon in physiology of the rice plant. Bulletin of the National Institute of Agronomic Science Serie B, v.15, p.1-58, 1965.

Received July 22, 2002

Accepted August 13, 2003 